LINGUISTIK : Jurnal Bahasa \& Sastra

http://jurnal.um-tapsel.ac.id/index.php/Linguistik

\title{
PENGARUH PENERAPAN METODE MAKE -A MATCH TERHADAP PENINGKATAN KEMAMPUAN MENULIS PANTUN JENAKA OLEH SISWA KELAS VIII SMP SWASTA THAWAALIB
}

\author{
Usman Safri / NIP. 196706031995111001 \\ STKIP USMAN SAFRI KUTACANE
}

\begin{abstract}
ABSTRAK
Penelitian ini bertujuan Untuk mengetahui apakah ada pengaruh penerapan metode make- a match terhadap peningkatan kemampuan menulis pantun jenaka oleh siswa kelas VII SMP Swasta Thawaalib. Berdasarkan pendapat tersebut di atas maka populasi dalam penelitian ini adalah seluruh siswa kelas VII SMP Swasta Thawaalib yang berjumlah 234 siswa yang terdiri dari 6 kelas. Sampel dalam penelitian ini berjumlah 41 siswa yaitu kelas VII, yang diambil dengan menggunakan teknik sampel purposive (purposive sampling). Peneliti menggunakan teknik purposif adalah dengan pertimbangan kelas VII.1 karena merupakan kelas inti. Berdasarkan hasil penelitian dan pembahasan yang telah diuraikan pada bab terdahulu maka dapat disimpulkan bahwa ada pengaruh penerapan metode make-a match terhadap peningkatan kemampuan menulis pantun jenaka oleh siswa kelas VII SMP Swasta Thawaalib. Hal ini terbukti dari nilai rata-rata tes awal 47,73 dan standar error sebesar 1,90 dan mengalami peningktan nilai hasil tes akhirnya dengan nilai rata-ratanya sebesar 81.31 diperoleh standar error tes kemampuan menulis pantun jenaka oleh siswa sebesar 0,9 , penerapan ada pengaruh penerapan metode make-a match terhadap peningkatan kemampuan menulis pantun jenaka oleh siswa kelas VII SMP Swasta Thawaalib. Selain itu, Dari tabel diatas diperoleh hasil $t_{\text {hitung }}=21,90$, selanjutnya dikonsultasikan dengan nilai $\mathrm{t}_{\text {tabel }}$ pada taraf signifikan $5 \%$ dengan $\mathrm{db}=\mathrm{N}-1=41$ $1=40$, maka diperoleh nilai $t_{\text {tabel }}=2,02$ Jadi dengan demikian nilai $t_{\text {hitung }} t_{\text {tabel }}$ atau diperoleh kesimpulan bahwa ada Pengaruh Penerapan Metode Make-A Match Terhadap Peningkatan Kemampuan Menulis Pantun Jenaka Oleh Siswa Kelas VII SMP Swasta Thawaalib.
\end{abstract}

Kata Kunci : Metode make - a match, menulis, Pantun 
PENDAHULUAN

$$
\text { Sastra dianggap mampu }
$$

membuka pintu hati pembacanya untuk menjadi manusia berbudaya, yakni manusia yang responsif terhadap lingkungan komunitasnya, mengukuhi keluhuran budi dalam hidup, dan berusaha menghindari perilaku negatif yang bisa menodai citra keharmonisan hidup. Hal itu terwujud apabila seseorang mempunyai tingkat apresiasi sastra cukup tinggi.

Salah satu solusi yang dapat digunakan untuk mengatasi masalah yang dihadapi adalah dengan mengembangkan metode pembelajaran yang dapat menciptakan suasana belajar yang aktif, menyenangkan, membantu siswa memahami materi pelajaran yang sulit, dan membantu guru mengajarkan materi yang kompleks, adalah metode pembelajaran make-a match. Metode make - a match ( mencari pasangan) merupakan salah satu jenis dari metode dalam pembelajaran kooperatif. Metode yang dikembangkan oleh Lorna Curran 1994. Salah satu keunggulan

e- ISSN 25489402 dari teknik ini adalah siswa mencari pasangan sambil belajar mengenal suaatu konsep atau topik, dalam suasana yang menyenangkan (Rusman, 2010:223). Penerapan metode ini dimulai dengan teknik, yaitu siswa disuruh mencari pasangan kartu yang merupakan jawaban/soal sebelum batas waktu, siswa yang dapat mencocokkan kartunya diberi poin.

Berdasarkan uraian di atas, maka peneliti bertujun melakukan penelitian yang berjudul: Pengaruh Penerapan Metode Make- A Match terhadap Peningkatan Kemampuan Menulis Pantun Jenaka Oleh Siswa kelas VII SMP Swasta Thawaalib.

\section{PEMBAHASAN}

\section{Kemampuan}

Menulis

\section{Pantun}

Menulis mempunyai peranan yang sangat penting bagi manusia. Menulis merupakan salah satu sarana komunikasi seperti halnya berbicara. Gie (2002:3) menytakan, menulis adalah segenap rangkaian seseorang mengungkapkan buah pikirannya melalui bahasa tulis kepada masyarakat pembaca untuk Vol.4 No.1 Januari - Juni 2019/ 31 
dipahami. Senada dengan pendapat

di atas Depdiknas (2005:1219) menyatakan, menulis adalah melahirkan pikiran atau perasaan dengan tulisan. Begitu juga Yunus (2007:13) menyatakan bahwa menulis adalah suatu kegiatan penyampaian pesan dengan menggunakan bahasa tulis sebagai medianya.

\section{Pantun}

\section{a. Pengertian Pantun}

Ada banyak pendapat tentang asal kata pantun, diantaranya sebagai berikut.(a) Kata pantun berasal dari kata umpama, misal, seperti, (b) pantun dalam bahasa Jawa disebut pari, yang berarti padi, (c) pantun berasal dari kata Vtun, kata vtun (bahasa kawi) dari kata tuntun atau tuntunan yang berarti mengatur. Dalam bahasa Philipina tuntun berarti teratur, dalam bahasa Tagalok tuntun berarti bicara menurut aturan tertentu. Dengan kata lain pantun berarti aturan atau susunan. (Darma, Yoce aliyah, 2007:2)

Menurut kamus besar Bahasa Indonesia (KBBI,2007:827), pantun ialah bentuk puisi Indonesia Melayu, tiap bait biasanya terdiri atas empat

e- ISSN 25489402 baris yang bersajak a-b-a-b, tiap larik biasanya terdiri atas empat kata, baris pertama dan baris kedua biasanya untuk tumpuan (sampiran) saja dan baris ketiga dan keempat merupakan isi.

\section{b. Struktur Pantun}

Struktur pantun adalah bentuk atau pola yang membentuk susunan pantun. Dilihat dari segi strukturnya pantun dibangun atas unsur bait, larik, rima, sampiran, dan isi. Selain unsure tersebut, sebuah pantun juga mementingkan irama pada waktu pengucapan atau penyampaian. Bait adalah banyaknya baris dalam sebuah pantun yaitu empat bsatu bait. Baris/larik adalah kumpulan beberapa kata yang memiliki arti dan bisa membentuk sampiran atau isi dalam sebuah pantun. Rima adalah pola akhir atau huruf vocal terakhir yang ada pada pantun. Sampiran adalah bagian pantun yang terletak pada baris 1-2 yang merupakan awal dari sebuah pantun atau sampiran merupakan unsure /sketsa pembayang suasana yang mengantarkan menuju isi atau maksud pantun tersebut. Isi adalah bagian pantun yang terletak pada Vol.4 No.1 Januari - Juni 2019/ 32 
baris 3-4 yang merupakan isi kandungan/ pokok atau tujuan dari pantun tersebut.

Sampiran merupakan penghantar agar pembaca mu membaca larik ketiga dan keempat. Sebaliknya isi merupakan maksud atau tujuan pantun. Isi pantun biasanya berisi pikiran, perasaan, nasihat, kebenaran, pertanyaan atauteka-teki. Isi pantun juga mengandung pesan yang disampaikan pemantun kepada orang lain (Bintang Angkasa Putra Raharja, 2008:3).

Lazimnya pantun terdiri atas empat larik satu bait, bersajak akhir dengan pola a-b-a-b. Semua bentuk pantun terdiri atas dua baagian: sampiran dan isi. Sampiran adalah dua baris pertama, kerap kali berkaitan dengan alam (mencirikan budaya agraris), masyarakat pendukungnya, dan biasanya tak punya hubungan dengan bagian kedua yang menyampaikan maksud selain untuk mengantarkan rima/sajak. Dua baris terakhir merupakan isi, yang merupakan tujuan dari pantun tersebut (http://id.wikipedia.org/wiki/Pantun).

\section{Metode Pembelajaran}

\section{a. Pengertian Metode Pembelajaran}

Metode pembelajaran adalah cara yang digunakan guru dalam mengorganisasikan kelas pada umumnya atau dalam menyajikan bahan pelajaran pada khususnya, Sagala, S. (2003:169). Sedangkan menurut Hatimah, I. (2000:10) menyatakan bahwa metode pembelajaran tidak hanya berfungsi sebagai cara untuk menyampaikan materi saja, melainkan berfungsi juga untuk pemberian dorongan, pengungkapan tumbuhnya minat belajar, penyampaian bahan belajar, pencipta iklim belajar yang kondusif, tenaga untuk melahirkan kreativitas, pendorong untuk penilaian diri dalam proses dan hasil belajar, dan pendorong dalam melengkapi kelemahan hasil belajar.

\section{Metode Pembelajaran Make -} A Match

\section{a. Pengertian}

Menurut Ramadhan (2008:32), metode pembelajaran make- a match atau mencari pasangan dikembangkan oleh Curran 1994. Salah satu keunggulan teknik Vol.4 No.1 Januari - Juni 2019/ 33 
ini adalah siswa mencari pasangan sambil belajar mengenai suatu konsep atau topik dalam suasana yang menyenangkan.

Tujuan dari metode make- a match atau mencari pasangan menurut Miftahul Huda, 2013:251) adalah sebagai berikut

1. Pendalaman materi'

2. Penggalian materi

3. Edutainment

\section{b. Langkah-Langkah Penerapan} Metode Make- A Match

Langkah -langkah penerapan metode make- a match menurut Huda (2013:252) adalah sebagai berikut.

1. Guru menyampaikan materi pembelajaran;

2. Siswa dibagi kedalam dua kelompok, misalnya kelompok A dan kelompok B. Kedua kelompok diminta untuk berhadap-hadapan;

3. Guru membagikan kartu pertanyaan kepada kelompok A dan kartu jawaban kepada kelompok B;

4. Guru menyampaikan kepada siswa bahwa mereka harus mencari/ mencocokkan kartu yang

e- ISSN 25489402 dipegang dengan kartu kelompok lain. Guru juga perlu menyampaikan batasan maksimal waktu yang diberikan kepada mereka.

5. Guru memint semua anggota kelompok A untuk mencari pasangannya di kelompok B. Jika mereka sudah menemukan pasangannya masing-masing, guru meminta mereka melaporkan diri kepadanya. Guru mencatat mereka pada kertas yang sudah dipersiapkan.

6. Jika waktu sudah habis, mereka harus diberitahu bahwa waktu sudah habis. Siswa yang belum menemukan pasangannya diminta untuk berkumpul sendiri.

7. Guru memanggil satu pasangan untuk presentasi. Pasangan lain dan siswa yang tidak mendapat pasangan memperhatikan dan memberikan tanggapan apakah pasangan itu cocok atau tidak.

8. Terakhir, guru memberikan konfimasi tentang kebenaran dan kecocokan pertanyaan dan jawaban dari pasangan yang memberikan presentasi.

Vol.4 No.1 Januari - Juni 2019/ 34 

9. Guru memanggil pasangan berikutnya, begitu seterusnya sampai seluruh pasangan melakukan presentasi.

\section{c. Kelebihan dan Kelemahan Metode Make- A match}

Adapun kelebihan metode make- a match menurut Miftahul Huda (2013:253) adalah sebagai berikut:

1. Dapat meningkatkan aktivitas belajar siswa, baik secara kognitif maupun fisik;

2. Karena ada unsure permainan, maka metode pembelajaran ini menyenangkan;

3. Meningkatkan pemahaman siswa terhadap materi yang dipelajari dan dapat meningkatkan motivasi belajar siswa.

4. Efektif sebagai sarana melatih keberanian siswa untuk tampil presentasi;

5. Efektif melatih kedisiplinan siswaa menghargai waktu belajar.

Adapun kelemahan metode pembelajaran make- a match menurut Miftahul Huda (2013:253) adalah sebagai berikut.

1. Jika metode pembelajaran ini tidak dipersiapkan dengan baik,

e- ISSN 25489402 akan banyak waktu yang terbuang;

2. Pada awal penerapan metode pembelajaran ini, banyak siswa yang akan malu berpasangan dengan lawan jenisnya;

3. Jika guru tidak mengarahkan siswa dengan baik, akan banyak siswa yang kurang memperhatikan pada saat peresentasi pasangan.

4. Guru harus hati-hati daan bijaksana saat memberikan hukuman pada yang tidak mendapatkan pasangan, karena mereka bisa malu;

5. Menggunakan model pembelajaran ini secara terus menerus akan menimbulkan kebosanan.

Pembelajaran menulis pantun, khususnya menulis pantun jenaka merupakan salah satu pembelajaran yang seharusnya menyenangkan, karena melalui pembelajaran siswa diajak bermain sambil merangkai kata-kata yang menarik dan menggugah perasaan. Namun, pada kenyataannya pembelajaran menulis pantun tersebut menjadi pembelajaran yang Vol.4 No.1 Januari - Juni 2019/ 35 
membosankan. Siswa hanya Menurut Sugiyono (2009:96), diajarkan syarat-syarat pantun saja dan hanya menghafal pantun-pantun yang sudah lama saja. Siswa kurang mampu merangkai kata-kata untuk membentuk sampiran dan isi dari pantun.

Pembelajaran menulis pantun melalui metode pembelajaran makea match atau mencari pasangan yang dikembangkan oleh Curran 1994, memiliki keunggulan yaitu siswa mencari pasangan sambil belajar mengenai suatu konsep atau topik dalam suasana yang menyenangkan. Pembelajaran melalui metode makea match memberikan manfaat bagi siswa, diantaranya mampu menciptakan suasana belajar aktif dan menyenangkan, materi pembelajaran yang disampaikan lebih menarik perhatian siswa, mampu meningkatkan hasil belajar siswa mencapai taraf ketuntasan belajar secara klasikal (Ramadan, 2008:32)

Hipotesis adalah suatu
$\begin{aligned} & \text { keadaan atau peristiwa yang } \\ & \text { diharapkan } \\ & \text { hubungan }\end{aligned}$
dan $\begin{array}{r}\text { menyangkut } \\ \text { penelitian }\end{array}$
(Setyosari, 2010:108).
e- ISSN 25489402
hipotesis merupakan jawaban sementara terhadap rumusan masalah penelitian, di mana rumusan masalah penelitian telah dinyatakan dalam bentuk pertanyaan. Dikatakan sementara karena jawaban yang diberikan baru didasarkan pada teori. Hipotesis dirumuskan atas dasar kerangka pikir yang merupakan jawaban sementara atas masalah yang dirumuskan. Berdasarkan penjelasan tersebut maka hipotesis dalam penelitian ini adalah Ada pengaruh penerapan metode make- a match terhadap peningkatan kemampuan menulis pantun jenaka oleh siswa kelas VII SMP Swasta Thawaalib.

\section{METODE PENELITIAN}

Jenis penelitian yang digunakan dalam penelitian ini merupakan jenis penelitian eksperimen yaitu suatu penelitian yang berusaha mencari pengaruh variabel tertentu terhadap variabel yang lain dalam kondisi yang terkontrol secara ketat. Rencana dan struktur penelitian yang digunakan untuk memperoleh jawaban atas permasalahan-permasalahan 
menggunakan rancangan satu variabel terikat $(\mathrm{X})$ dan peningkatan kelompok dengan preetes- postes ( kemampuan menulis pantun sebagai one group pretest-posttest design). variabel bebas (Y). Menurut Rancangan penelitian oneSugiyono (2006:90), Populasi adalah group pretest-posttest menurut Gall (2003) dalam Setyosari (2013:182) meliputi tiga langkah yaitu (1) pelaksanaan pretes untuk mengukur variabel terikat; (2) pelaksanaan perlakuan; dan (3) pelaksanaan posttest untuk mengukur hasil atau dampak terhadap variabel terikat. Dengan demikian, dampak perlakuan ditentukan dengan cara membandingkan skor hasil pretest dan post test. Penelitian ini direncanakan di SMP Swasta Thawaalib. Penentuan lokasi berdasarkan pertimbanganpertimbangan berikuk. Adanya kemudahan memperoleh data. Jumlah siswa cukup memadai untuk dijadikan sampel penelitian. Di sekolah tersebut belum pernah diadakan penelitian dengan masalah yang sama. Waktu penelitian di laksanakan pada Agustus 2018.

Variabel dalam penelitian ini adalah pengaruh penerapan metode metode make- a match sebagai wilayah generalisasi yang terdiri atas objek/subjek yang mempunyai kualitas dan karakteristik tertentu yang ditetapkan oleh peneliti untuk dipelajari dan kemudian disimpulkan. Sujana menyatakan (2002:30): populasi merupakan totalitas semua yang memungkinkan hasil menghitung atau pengukuran, kuantitas maupun kualitas dari pada karakteristik tertentu mengenai sekumpulan objek yang lengkap dan jelas yang ingin dipelajari sifat-sifatnya.

Berdasarkan pendapat tersebut di atas maka populasi dalam penelitian ini adalah seluruh siswa kelas VII SMP Swasta Thawaalib Tahun Pembelajaran 2015-2016 yang berjumlah 234 siswa yang terdiri dari 6 kelas sebagaiman dalam tabel berikut.

Tabel 3.1 Jumlah populasi

\begin{tabular}{|l|l|l|}
\hline Nomor & Kelas & Populasi \\
\hline 1 & VII.1 & 41 siswa \\
\hline
\end{tabular}

Vol.4 No.1 Januari - Juni 2019/ 37 
LINGUISTIK : Jurnal Bahasa \& Sastra

http://jurnal.um-tapsel.ac.id/index.php/Linguistik

\begin{tabular}{|l|l|l|}
\hline & & \\
\hline 2 & VII.2 & 44 siswa \\
\hline 3 & VII.3 & 41 siswa \\
\hline 4 & VII.4 & 41 siswa \\
\hline 5 & VII.5 & 42 siswa \\
\hline 6 & VII.6 & 25 siswa \\
\hline & & \\
\hline & Jumlah & 234 Siswa \\
\hline
\end{tabular}

Sumber: Wakil Kepala Sekolah

Bidang Kesiswaan

Nasution

(2008:86)

menyatakan bahwa sampel adalah sebagian dari populasi. Sedangkan Sukardi (2003:54) menyatakan bahwa sampel adalah bagian dari jumah populasi yang dipiih untuk sumber data. Pengambilan sampel harus dilakukan sedemikian rupa sehingga diperoleh sampel yang benar-benar dapat berfungsi sebagai contoh atau dapat menggambarkan keadaan popuasi sebenarnya. Dengan istilah lain, sampel harus representatif.

e- ISSN 25489402
Sampel dalam penelitian ini berjumlah 41 siswa yaitu kelas VII, yang diambil dengan menggunakan teknik sampel purposive (purposive sampling). (Punajif cvvv 2013:201) menyatakan "Teknik sampel purposif adalah teknik pengambilan sampel dengan pertimbangan tertentu berkenaan dengan sampel yang akan diambil. Sampel yang digunakan dalam penelitian cukup dari suatu unit saja."

Berdasarkan pendapat tersebut di atas, adapun alasan peneliti menggunakan teknik purposif adalah dengan pertimbangan kelas VII.1 karena merupakan kelas inti.

Tabel 3.2 Jumlah Sampel

\begin{tabular}{|c|c|c|}
\hline Nomor & Kelas & Sampel \\
\hline 1 & IX.1 & 41 \\
\hline & Jumlah & 41 \\
\hline
\end{tabular}

merupakan suatu tahapan yang sangat menentukan dalam suatu penelitian. Kesalahan dalam melakukan pengumpulan data akan menyebabkan tidak akuratnya data penelitian yang akan menyebabkan kesimpulan yang dibuat akan

Vol.4 No.1 Januari - Juni 2019/ 38 
mengalami kesalahan. Untuk itu pengumpulan data memerlukan perencanaan yang matang dan teliti.

Data yang dikumpulkan dalam penelitian berupa skor tes. Data skor tes ini adalah skor hasil tes awal dan skor hasil tes akhir, akan diolah melalui analisis deskriptif.

Teknik analisis data dilakukan dengan menggunakan langkahlangkah sebagai berikut.

1. Mentabulasi skor tes awal

2. Mentabulasi skor tes akhir

3. Menentukan skor tertinggi dan skor terendah dari hasil tes awal dan tes akhir.

4. Menghitung rata-rata skor variabel hasil tes awal dan tes akhir dengan rumus berikut.

$$
\mathrm{M}=\frac{\sum f x}{N}
$$

Keterangan:

$$
\begin{aligned}
& \mathrm{M}=\text { rata-rata (mean) } \\
& \sum f \mathrm{x}=\text { jumlah }
\end{aligned}
$$

frekuensi

$$
\mathrm{N}=\text { jumlah sampel }
$$

5. Menghitung standar deviasi hasil tes awal dan tes akhir dengan rumus.

$$
\mathrm{SD}=\sqrt{\frac{\sum f x^{2}}{N}}
$$

Keterangan:

e- ISSN 25489402
$\mathrm{SD}=$ standar deviasi

$$
\sum \mathrm{f} x^{2}=\text { kuadrat }
$$

jumlah frekuensi

$$
\mathrm{N}=\text { jumlah sampel }
$$

6. Menghitung standar eror dari variabel hasil tes awal dan tes akhir

$$
\mathrm{S} E_{m}=\frac{S D}{N-1}
$$

Keterangan:

$$
\begin{aligned}
& \mathrm{SD}=\text { standar deviasi } \\
& \mathrm{s} E_{m=} \text { standar error } \\
& \mathrm{N}=\text { jumlah sampel }
\end{aligned}
$$

7. Setelah hasil standar error diperoleh, selanjutnya mencari perbedaan hasil standar error pada kedua kelompok dengan menggunakan rumus berikut.

$$
\begin{aligned}
& \mathrm{S} E_{m x-M Y} \\
& =\sqrt{S E^{2 m x+S E^{2} M y}}
\end{aligned}
$$

Keterangan:

$$
\begin{aligned}
& \mathrm{SE}=\text { standar error } \\
& \text { perbedaan } \\
& \text { kelompok } \\
& \mathrm{SE}_{\mathrm{mx}}=\text { standar eror } \\
& \text { tes awal } \\
& \mathrm{SE}_{\mathrm{MY}}=\text { standar eror } \\
& \text { tes akhir }
\end{aligned}
$$

\section{Menguji Hipotesis}

Untuk menguji hipotesis menggunakan uji statistik t yaitu:

Vol.4 No.1 Januari - Juni 2019/ 39 


$$
\mathrm{t}_{\mathrm{o}}=\frac{M_{x-M_{y}}}{S E_{m x}-M_{y}}
$$

Keterangan :

$$
\begin{aligned}
& \text { to }=\mathrm{t} \\
& \text { observasi } \\
& \text { Mx = mean } \\
& \text { hasil tes awal } \\
& \text { My = mean } \\
& \text { hasil tes akhir } \\
& \mathrm{SE}_{\mathrm{MX}}-\mathrm{MY}= \\
& \text { standar }
\end{aligned}
$$

dimana:

$$
\begin{aligned}
& S E_{M}=\frac{S D}{\sqrt{N-1}} \\
& \mathrm{~S} E_{M X-M Y}=\sqrt{\frac{\sum f x^{2}}{N}}
\end{aligned}
$$

Asumsi hipotesis

$$
\text { Apabila } \mathrm{t}_{\text {hitung }}<\mathrm{t}_{\text {tabel }} \text { maka }
$$
hipotesis ditolak.

Apabila $t_{\text {hitung }}>t_{\text {tabel }}$ maka hipotesis diterima.

\section{HASIL PENELITIAN}

Penelitian ini bertujuan untuk mengetahui Pengaruh Penerapan Metode Make-A Match Terhadap Peningkatan Kemampuan Menulis Pantun Jenaka Oleh Siswa Kelas VII SMP Swasta Thawaalib Tahun Pembelajaran 2016-2017. Berikut ini adalah data hasil penelitian yang diperoleh dari hasil tes awal dan tes akhir siswa. adapun penyajian datanya dilihat pada table 4.1 berikut ini:

Tabel 4.1. Hasil Penilaian Kemampuan Menulis Pantun Jenaka Oleh Siswa

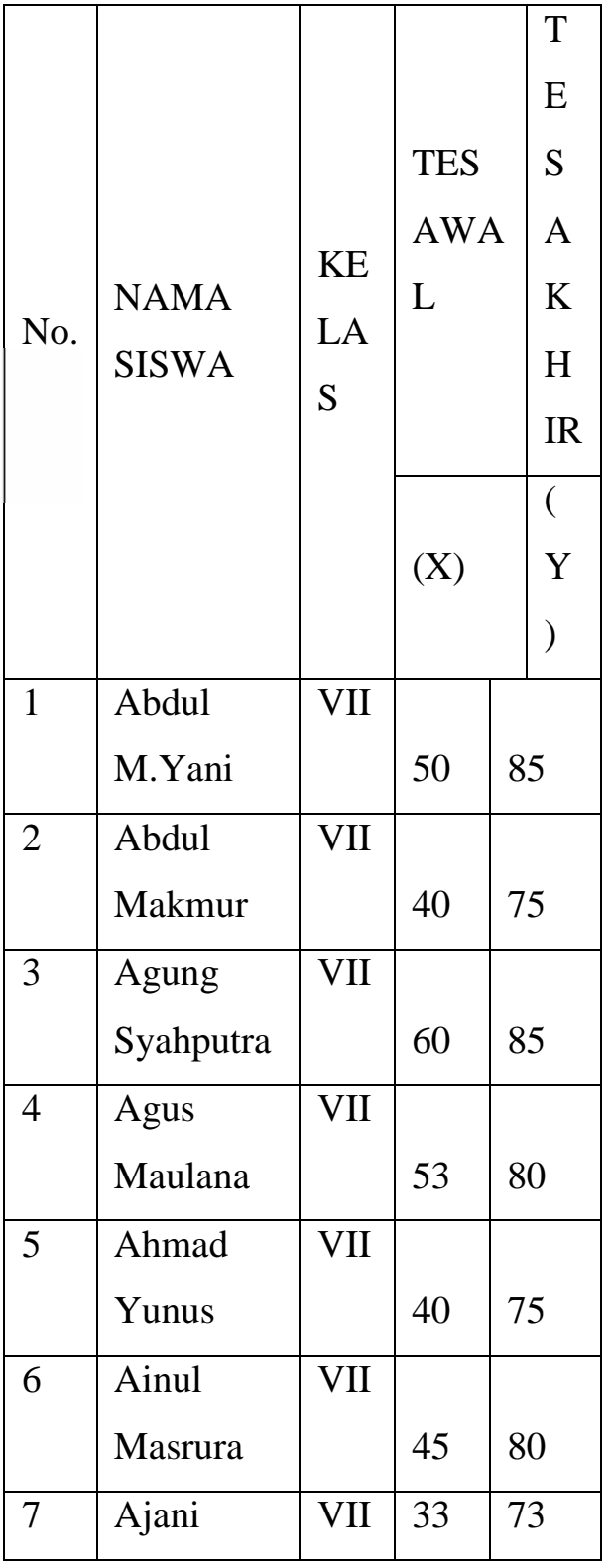

Vol.4 No.1 Januari - Juni 2019/ 40 
LINGUISTIK : Jurnal Bahasa \& Sastra

http://jurnal.um-tapsel.ac.id/index.php/Linguistik

\begin{tabular}{|c|c|c|c|c|}
\hline & Iqbal Pelis & & & \\
\hline 8 & $\begin{array}{l}\text { Akbar } \\
\text { Maulana }\end{array}$ & VII & 30 & 80 \\
\hline 9 & $\begin{array}{l}\text { Al Ilal } \\
\text { Azmi }\end{array}$ & VII & 30 & 80 \\
\hline 10 & Alda & VII & 66 & 87 \\
\hline 11 & Aldi & VII & 53 & 73 \\
\hline 12 & $\begin{array}{l}\text { Aldi } \\
\text { Mustafa }\end{array}$ & VII & 55 & 85 \\
\hline 13 & Alfatawi & VII & 60 & 86 \\
\hline 14 & $\begin{array}{l}\text { Almaida } \\
\text { Sari }\end{array}$ & VII & 45 & 80 \\
\hline 15 & Alpariji & VII & 33 & 75 \\
\hline 16 & $\begin{array}{l}\text { Alvin } \\
\text { Irwansyah }\end{array}$ & VII & 40 & 75 \\
\hline 17 & $\begin{array}{l}\text { Alwaradi } \\
\text { Sukma }\end{array}$ & VII & 55 & 87 \\
\hline 18 & $\begin{array}{l}\text { Anggi } \\
\text { Angreani }\end{array}$ & VII & 60 & 87 \\
\hline 19 & Anisa & VII & 50 & 87 \\
\hline 20 & $\begin{array}{l}\text { Annisa } \\
\text { Putri }\end{array}$ & VII & 50 & 85 \\
\hline 21 & $\begin{array}{l}\text { Arib } \\
\text { Rabulah }\end{array}$ & VII & 50 & 86 \\
\hline 22 & Badrun & VII & 40 & 87 \\
\hline 23 & $\begin{array}{l}\text { Bahri } \\
\text { Rijki }\end{array}$ & VII & 30 & 70 \\
\hline 24 & $\begin{array}{l}\text { Bambang } \\
\text { Susanto }\end{array}$ & VII & 66 & 86 \\
\hline 25 & Budiman & VII & 34 & 70 \\
\hline
\end{tabular}

\begin{tabular}{|c|c|c|c|c|}
\hline & Sah & & & \\
\hline 26 & $\begin{array}{l}\text { Cahaya } \\
\text { Wulandari }\end{array}$ & VII & 65 & 87 \\
\hline 27 & $\begin{array}{l}\text { Cici } \\
\text { Nabila }\end{array}$ & VII & 65 & 85 \\
\hline 28 & $\begin{array}{l}\text { Cita } \\
\text { Wulan } \\
\text { Dari }\end{array}$ & VII & 66 & 87 \\
\hline 29 & Delia & VII & 53 & 80 \\
\hline 30 & $\begin{array}{l}\text { Desi } \\
\text { Ratna Sari }\end{array}$ & VII & 53 & 85 \\
\hline 31 & Dia Usiva & VII & 60 & 87 \\
\hline 32 & $\begin{array}{l}\text { Diki } \\
\text { Selian }\end{array}$ & VII & 30 & 70 \\
\hline 33 & $\begin{array}{l}\text { Dinda } \\
\text { Paradila }\end{array}$ & VII & 40 & 85 \\
\hline 34 & $\begin{array}{l}\text { Dipa } \\
\text { Aryanto }\end{array}$ & VII & 50 & 87 \\
\hline 35 & $\begin{array}{l}\text { Dyan Puzi } \\
\text { Hastuti }\end{array}$ & VII & 34 & 80 \\
\hline 36 & $\begin{array}{l}\text { Eka } \\
\text { Purnama }\end{array}$ & VII & 30 & 75 \\
\hline 37 & $\begin{array}{l}\text { Embun } \\
\text { Jaya }\end{array}$ & VII & 50 & 85 \\
\hline 38 & Fahru & VII & 34 & 80 \\
\hline 39 & $\begin{array}{l}\text { Feri } \\
\text { Gunawan }\end{array}$ & VII & 60 & 70 \\
\hline 40 & $\begin{array}{l}\text { Fitry } \\
\text { Handayani } \\
\text { Pelis }\end{array}$ & VII & 65 & 87 \\
\hline
\end{tabular}

e- ISSN 25489402

Vol.4 No.1 Januari - Juni 2019/ 41 
LINGUISTIK : Jurnal Bahasa \& Sastra

http://jurnal.um-tapsel.ac.id/index.php/Linguistik

\begin{tabular}{|c|c|c|c|c|}
\hline 41 & $\begin{array}{l}\text { Galiwan } \\
\text { Abdan }\end{array}$ & VII & 34 & 85 \\
\hline
\end{tabular}

\section{A. Pembahasan Hasil Penelitian}

1. Deskripsi Data Tes Awal

Penerapan Metode Make-A

Match

Terhadap

Peningkatan Kemampuan

Menulis Pantun Jenaka Oleh

Siswa Sebelum Pembelajaran

Berikut ini adalah hasil analisis data penelitian yang diperoleh dari tes awal Penerapan Metode Make-A Match Terhadap Peningkatan Kemampuan Menulis Pantun Jenaka Oleh Siswa Kelas VII SMP Swasta Thawaalib Tahun Pembelajaran 2016-2017. Adapun penyajian datanya dapat dilihat pada table 4.2 sebagai berikut.

Tabel 4.2. Hasil Tes Awal Menulis Pantun Jenaka Oleh Siswa

\begin{tabular}{|l|l|}
\hline Nilai Tes Awal & Frequency \\
\hline 30.00 & 5 \\
\hline 33.00 & 2 \\
\hline 34.00 & 4 \\
\hline 40.00 & 5 \\
\hline
\end{tabular}

e- ISSN 25489402

\begin{tabular}{||l|l|}
\hline 45.00 & 2 \\
\hline 50.00 & 6 \\
\hline 53.00 & 4 \\
\hline 55.00 & 2 \\
\hline 60.00 & 5 \\
\hline 65.00 & 3 \\
\hline 66.00 & 3 \\
\hline Total & 41 \\
\hline
\end{tabular}

Dari table 4.2 diatas nilai rata-rata, dan standar devisiasinya dapat dihitung menggunakan analisis spss 19 for windows sebagai berikut:

Tabel 4.3.Deskriptif Data Tes Awal Menulis Pantun Jenaka

\section{Oleh Siswa}

\begin{tabular}{|l|l|l|l|l|l|l|}
\hline & & Min & Max & M & Std. & ari \\
& imu & imu & ea & Devia & an \\
m & $\mathrm{m}$ & $\mathrm{n}$ & tion & ce \\
\hline Tes & 41 & 30.0 & 66.0 & 47. & 12.21 & 14 \\
Awa & & 0 & 0 & 73 & 684 & 9. \\
l & & & & 17 & & 25 \\
Vali & 41 & & & & & 1 \\
d N & & & & & & \\
(list & & & & & & \\
wise & & & & & & \\
) & & & & & & \\
\hline
\end{tabular}

Vol.4 No.1 Januari - Juni 2019/ 42 
LINGUISTIK : Jurnal Bahasa \& Sastra

http://jurnal.um-tapsel.ac.id/index.php/Linguistik

Sumber : Analisis Data dengan SPSS

19 for windows

a. Rata-rata Tes Awal

Dari table 4.3 diatas rata-rata Penerapan Metode Make-A Match Terhadap Peningkatan Kemampuan Menulis Pantun Jenaka Oleh Siswa sebelum diberikan pembelajaran adalah sebesar 47,73 dan termasuk dalam kategori kurang.

b. Standar Devisiasi

Dari table 4.3 diatas standar devisiasi Penerapan Metode Make-A Match Terhadap Peningkatan Kemampuan Menulis Pantun Jenaka Oleh Siswa sebelum diberikan pembelajaran adalah sebesar adalah 12,21

\section{Deskripsi Data Tes Akhir} Penerapan Metode Make-A Match Terhadap Peningkatan Kemampuan Menulis Pantun Jenaka Oleh Siswa Sesudah Diberikan Pembelajaran

Berikut ini adalah hasil analisis data penelitian yang diperoleh dari tes akhir Penerapan Metode Make-A Match Terhadap e- ISSN 25489402
Peningkatan Kemampuan Menulis Pantun Jenaka Oleh Siswa Kelas VII SMP Swasta Thawaalib Tahun Pembelajaran 2016-2017. Adapun penyajian datanya dapat dilihat pada table 4.2 sebagai berikut:

Tabel 4.4. Hasil Tes Akhir Menulis Pantun Jenaka Oleh Siswa

\begin{tabular}{|l|l|}
\hline Nilai Tes Akhir & Frequency \\
\hline 70.00 & 4 \\
\hline 73.00 & 2 \\
\hline 75.00 & 5 \\
\hline 80.00 & 8 \\
\hline 85.00 & 9 \\
\hline 86.00 & 3 \\
\hline 87.00 & 10 \\
\hline Total & 41 \\
\hline
\end{tabular}

Dari table 4.4 diatas nilai rata-rata, dan standar devisiasinya dapat dihitung menggunakan analisis spss 19 for windows sebagai berikut:

\section{Tabel 4.5.Deskriptif Data Tes} Akhir Menulis Pantun Jenaka Oleh Siswa

\begin{tabular}{|l|l|l|l|l|l|l|}
\hline & & Mi & & & Std. & Va \\
& ni & Ma & M & Devi & ria \\
& mu & xim & ea & atio & nc \\
& N & m & um & n & n & e \\
\hline
\end{tabular}

Vol.4 No.1 Januari - Juni 2019/ 43 


\begin{tabular}{|l|r|r|r|r|r|r|}
\hline Tes & 41 & 70. & 87. & 81 & 5.86 & 34 \\
Akhi & & 00 & 00 & .3 & 276 & .3 \\
$\mathrm{r}$ & & & & 17 & & 72 \\
Vali & 41 & & & & & \\
d N & & & & & & \\
(list & & & & & & \\
wise & & & & & & \\
\hline
\end{tabular}

Sumber : Analisis Data dengan SPSS

19 for windows

a. Rata-rata Tes Awal

Dari tabel 4.5 diatas rata-rata Penerapan Metode Make-A Match Terhadap Peningkatan Kemampuan Menulis Pantun Jenaka Oleh Siswa sesudah diberikan pembelajaran adalah sebesar 81.31 dan termasuk dalam kategori baik. Berdasarkan data nilai tes awal dan tes akhir siswa tersebut dapat diketahui bahwa ada Pengaruh Penerapan Metode MakeA Match Terhadap Peningkatan Kemampuan Menulis Pantun Jenaka Oleh Siswa Kelas VII SMP Swasta Thawaalib Tahun Pembelajaran 2016-2017.

b. Standar Devisiasi
Dari table 4.5 diatas standar devisiasi Penerapan Metode Make-A Match Terhadap Peningkatan Kemampuan Menulis Pantun Jenaka Oleh Siswa sesudah diberikan pembelajaran adalah sebesar adalah 5,85

3. Menghitung Standar Error dari Hasil Tes Awal dan Tes Akhir

Adapun untuk perhitungan standar error tes awal dan tes akhir dari Penerapan Metode Make-A Match Terhadap Peningkatan Kemampuan Menulis Pantun Jenaka Oleh Siswa adalah sebagai berikut:

a. Standar Eror Tes Awal

\section{Tabel 4.6 Standar Eror Tes Awal Menulis Pantun Jenaka Oleh Siswa}

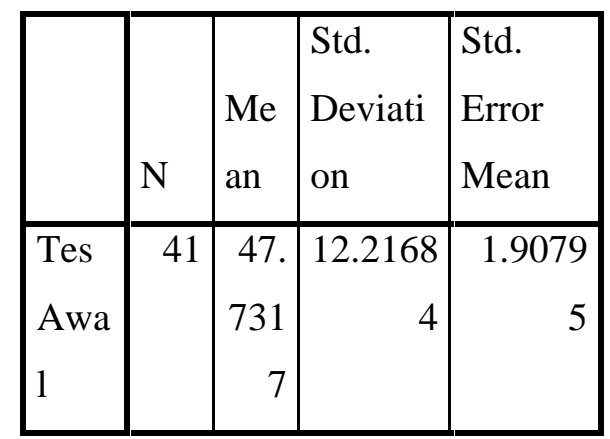

Sumber : Analisis Data

dengan SPSS 19 for windows 
Dari analisis data dengan spss 19 for windows dengan jumlah sampel 41 dan nilai rata-rata 47,73 di peroleh Standar error Kemampuan Menulis Pantun Jenaka Oleh Siswa sebesar 1,90

b. Standar Eror Tes Akhir

Tabel 4.7 Standar Eror Tes Akhir Menulis Pantun Jenaka Oleh Siswa

\begin{tabular}{|c|c|c|c|c|}
\hline & $\mathrm{N}$ & $\begin{array}{l}\text { Mea } \\
n\end{array}$ & \begin{tabular}{|l} 
Std. \\
Deviatio \\
$\mathrm{n}$
\end{tabular} & $\begin{array}{l}\text { Std. } \\
\text { Error } \\
\text { Mean }\end{array}$ \\
\hline $\begin{array}{l}\text { Tes } \\
\text { Akhi } \\
\text { r }\end{array}$ & 41 & $\begin{array}{r}81.3 \\
171\end{array}$ & 5.86276 & .91561 \\
\hline
\end{tabular}

dengan SPSS 19 for windows

Dari analisis data dengan spss 19 for windows dengan jumlah sampel 41 dan nilai rata-rata $81.31 \mathrm{di}$ peroleh Standar error tes Kemampuan Menulis Pantun Jenaka Oleh Siswa sebesar 0,91.

c. Perbedaan hasil standar eror dari tes awal dan tes akhir

Tabel 4.8 Standar Eror Tes Awal dan Tes Akhir Menulis Pantun Jenaka Oleh Siswa

\begin{tabular}{|l|l|l|l|l|}
\hline & & $\begin{array}{l}\text { M } \\
\text { ea }\end{array}$ & $\begin{array}{l}\text { Std. } \\
\text { Devia } \\
\text { tion }\end{array}$ & $\begin{array}{l}\text { Std. } \\
\text { Error } \\
\text { Mean }\end{array}$ \\
\hline Nilai & 82 & 64 & 19.39 & 2.1417 \\
Tes & & .5 & 468 & 8 \\
Awal - & & & \\
Tes & & 4 & & \\
Akhir & & & & \\
\hline
\end{tabular}

Sumber : Analisis Data dengan SPSS 19 for windows

Dari analisis data dengan spss 19 for windows peroleh Standar error tes kemampuan awal menulis wacana eksposisi sebesar 2,14

4. Pengujian Hipotesis

Adapun pengujian hipotesis statistikuntuk mengetahui Pengaruh Penerapan Metode Make-A Match Terhadap Peningkatan Kemampuan Menulis Pantun Jenaka Oleh Siswa Kelas VII SMP Swasta Thawaalib Tahun Pembelajaran 2016-2017 tersebut menggunakan uji t. uji $t$ dilakukan dengan analisis spss 19 for windows. hasil analisis uji $\mathrm{t}$ menggunakan analisis spss 19 for windows dapat dilihat pada tabel berikut: 
Tabel 4.7 Ringkasan Hasil Uji t Penerapan Metode Make-A Match Terhadap Peningkatan Kemampuan Menulis Pantun Jenaka Oleh Siswa

\section{Paired Samples Test}

\begin{tabular}{|c|c|c|c|c|c|c|c|c|}
\hline & \multicolumn{5}{|c|}{ Paired Differences } & \multirow[b]{3}{*}{$\mathrm{t}$} & \multirow[b]{3}{*}{ df } & \multirow{3}{*}{$\begin{array}{l}\text { Sig } \\
\cdot \\
(2- \\
\text { tail } \\
\text { ed) }\end{array}$} \\
\hline & \multirow[b]{2}{*}{ Mean } & \multirow{2}{*}{$\begin{array}{l}\text { Std. } \\
\text { Deviati } \\
\text { on }\end{array}$} & \multirow{2}{*}{$\begin{array}{l}\text { Std. Error } \\
\text { Mean }\end{array}$} & \multicolumn{2}{|c|}{$\begin{array}{l}\text { 95\% Confidence } \\
\text { Interval of the } \\
\text { Difference }\end{array}$} & & & \\
\hline & & & & Lower & Upper & & & \\
\hline $\begin{array}{ll}\text { Pai } & \text { Tes A } \\
\text { r 1 } & \text { Wal-Tes } \\
& \text { Akhir }\end{array}$ & $\begin{array}{r}33.585 \\
37\end{array}$ & 9.81574 & 1.53296 & $\begin{array}{r}- \\
36.68360\end{array}$ & $\begin{array}{r}- \\
30.4871 \\
4\end{array}$ & \begin{tabular}{r|}
21.9 \\
09
\end{tabular} & 40 & $\begin{array}{r}.00 \\
0\end{array}$ \\
\hline
\end{tabular}

Dari tabel diatas diperoleh hasil

dapat disimpulkan bahwa ada $\mathrm{t}_{\text {hitung }}=21,90, \quad$ selanjutnya pengaruh penerapan metode make-a dikonsultasikan dengan nilai $t_{\text {tabel }}$ match terhadap peningkatan pada taraf signifikan $5 \%$ dengan $\mathrm{db}=$ kemampuan menulis pantun jenaka $\mathrm{N}-1=41-1=40$, maka diperoleh oleh siswa kelas VII SMP Swasta nilai $t_{\text {tabel }}=2,02$ Jadi dengan demikian nilai $t_{\text {hitung }} t_{\text {tabel }}$ atau Thawaalib. Hal ini terbukti dari nilai diperoleh kesimpulan bahwa ada rata-rata tes awal 47,73 dan standar Pengaruh Penerapan Metode Makeerror sebesar 1,90 dan mengalami peningktan nilai hasil tes akhirnya A Match Terhadap Peningkatan dengan nilai rata-ratanya sebesar Kemampuan Menulis Pantun Jenaka Oleh Siswa Kelas VII SMP Swasta 81.31 diperoleh standar error tes kemampuan menulis pantun jenaka Thawaalib.

\section{SIMPULAN}

Berdasarkan hasil penelitian dan pembahasan yang telah diuraikan pada bab terdahulu maka oleh siswa sebesar 0,9, penerapan ada pengaruh penerapan metode make-a match terhadap peningkatan kemampuan menulis pantun jenaka oleh siswa kelas VII SMP Swasta Thawaalib. 
Selain itu, Dari tabel diatas diperoleh hasil $\quad t_{\text {hitung }}=21,90, \quad$ selanjutnya dikonsultasikan dengan nilai $t_{\text {tabel }}$ pada taraf signifikan $5 \%$ dengan $\mathrm{db}=\mathrm{N}-1=41-1=40$, maka diperoleh nilai $t_{\text {tabel }}=2,02$ Jadi dengan demikian nilai $t_{\text {hitung }} t_{\text {tabel }}$ atau diperoleh kesimpulan bahwa ada Pengaruh Penerapan Metode Make-A Match Terhadap Peningkatan Kemampuan Menulis Pantun Jenaka Oleh Siswa Kelas VII SMP Swasta Thawaalib.

\section{DAFTAR PUSTAKA}

Sagala, Syaiful. 2006. Konsep dan Makna Pembelajaran. Bandung: Alfabet.

Setyosari, Punaji.2010. Metode Penelitian Pendidikan dan Pengembangnnya, Jakarta: Kencana.

Sudjana, Nana, Penilaian Hasil Proses Belajar Mengajar, Bandung: PT. Remaja Rosdakarya, 1989.

Sugiyono, Statistika untuk Penelitian, Bandung: Alfabeta, 2010.

Sukardi.2002. Proses Belajar Mengajar di Sekolah, Jakarta: Rineka Cipta, 2002.

Syah, Muhibbin, Psikologi Pendidikan, Bandung: PT Remaja Rosdakarya, 2010. Tim. 